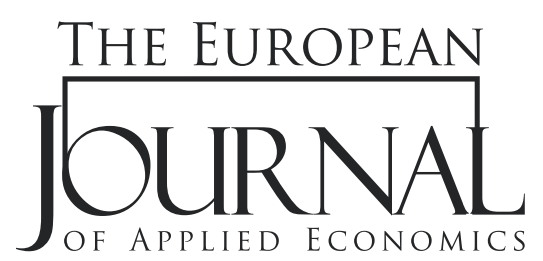

\section{ANTECEDENTS OF MOBILE BANKING: UTAUT MODEL}

\author{
Jovana Savić* , Aleksandra Pešterac \\ Faculty of Economics, University of Kragujevac, PhD students \\ Kragujevac, Serbia
}

EJAE 2019, 16(1): 20-29

ISSN 2406-2588

UDK: 336.71:[621.395.721.5:004.77

336.717:336.745

DOI: 10.5937/EJAE15-19381

Original paper/Originalni naučni rad

\section{Article info:}

Received: November 1, 2018

Correction: November 15, 2018

Accepted: December 10, 2018 opment of mobile banking systems are extremely high, knowledge of which factors affect the intentions of individuals to use mobile banking services can be of great importance. For this purpose, empirical research was conducted and 313 respondents were surveyed in the territory of Sumadija, Central Serbia. The collected primary data were analyzed using the statistical software SPSS v. 20. To examine the factors in the work, the UTAUT model (Unified Theory of Acceptance and Use of Technology) was used. The results of empirical research indicate that all components of the UTAUT model have statistically significant influence on intention to use mobile banking, with performance expectancy singled out as the most important antecedent, while effort expectancy has the weakest impact. The paper confirms the success of the UTAUT model for testing mobile banking antecedents, and gains new insights regarding the intention of using mobile banking in Serbia that can serve for managerial purposes.

\section{Keywords:}

modern technologies,

mobile banking,

intention to use mobile banking, UTAUT model.

\title{
INTRODUCTION
}

The rapid development of modern information technology and an increase in the number of mobile users have caused the emergence of a new trend in banking operations, known as mobile banking. Mobile banking was developed as an extension of Internet banking, and is based on the use of modern mobile technology to provide clients with various banking and financial services (Yao \& Zhong, 2011). On the other hand, mobile banking is a part of mobile commerce, and can therefore be defined as the evolution of the e-commerce paradigm from fixed line networks to wireless data networks (Samudra 
\& Phadtare, 2012, p. 51). Using the benefits of mobile devices, mobile banking allows clients to conduct banking transactions at any time and from any place. Activities that can be performed by mobile banking include paying bills, transferring money, finding ATM locations, information inquiry, account management, etc. (Afshan \& Sharif, 2016).

Providing quality and diverse mobile banking services to clients is a priority for today's banks. However, since mobile banking implies the development of complex systems that require very high investments, for the banking sector it is particularly important to learn about the factors that influence the intentions of clients to use mobile banking services, as it can help them when deciding on investments in mobile banking. As mobile banking is a trend in the banking industry that is still developing, especially in the territory of Serbia, the number of mobile banking users is still small (Yao \& Zhong, 2011; Alalwan et al., 2017). Stated reasons for this include mistrust in the security of service delivery, risks, the danger of fraud, lack of awareness, and technical issues during the realization of banking transactions (Sanader, 2014; Bhatt \& Bhatt, 2016). In this regard, it is concluded that new research on the antecedents of mobile banking is necessary in order to provide the banking sector with better and more complete information that can serve as a good basis for making optimal business decisions.

Starting from the abovementioned, the paper presents the results of the empirical research conducted in order to identify key antecedents behind the intentions of clients in the territory of Sumadija, Central Serbia, to use mobile banking services. The UTAUT model was used as the initial research model, which has become very popular in research literature for testing the process of adopting technology, but which, to the authors' knowledge, was not used too much in the research of domestic authors when it comes to segment of mobile banking. Therefore, the contribution of the work is also reflected in the practical testing of the UTAUT model in this segment, apart from the knowledge related to the antecedents of mobile banking.

\section{LITERATURE REVIEW AND HYPOTHESES DEVELOPMENT}

Understanding the factors that influence technology acceptance has become the subject of research for a large number of authors. For these purposes, based on psychological and sociological theories, many models have been developed, where the most widely used was the technology acceptance model. Using the foundations of research by authors in the field of technology acceptance, Venkatesh et al. (2003) developed the UTAUT model (Unified Theory of Acceptance and Use of Technology). The UTAUT model was created as a result of the integration of eight models used in previous research to explain the process of adopting technology, such as The Theory of Reasoned Action, The Technology Acceptance Model, The Motivational Model, The Theory of Planned Behavior, The Combined Theory of Planned Behavior/Technology Acceptance Model, The Model of Personal Computer Utilization, The Diffusion of Innovation Theory and Social Cognitive Theory (Samudra \& Phadtare, 2012). The UTAUT model has attracted the attention of a large number of researchers and the success of its application has been confirmed in plenty of empirical research (Venkatesh et al., 2003, 2012; Venkatesh \& Zhang 2010; Yu, 2012; Alkhunaizan \& Love, 2012; Baptista \& Oliveira, 2015). Its importance is reflected in not only allowing to analyze the most important antecedents of technology use, but also in allowing the analysis of moderators that amplify or constrain the effects of core determinants ( $\mathrm{Yu}, 2012)$. The UTAUT model includes four constructs: performance expectancy, effort expectancy, social influence, and facilitating conditions (Venkatesh et al., 2011). In addition, the UTAUT model includes gender, age, experience and voluntariness of use as moderating factors, which explain the behavioral differences of different groups of people (Min et al., 2008).

Performance expectancy is defined as the degree to which using a technology will provide benefits to consumers in performing certain activities (Adapted from: Venkatesh et al., 2003). Performance 
expectancy actually measures the degree to which a person believes that using mobile banking services will help them in performing banking transactions (Adapted from: Tarhini et al., 2016). Oliveira et al. (2014) and Sarfaraz (2017) have come to the conclusion that performance expectancy has a total effect on behavioral intentions towards mobile banking. Baptista \& Oliveira (2015) and Basri (2018) have empirically shown that mobile banking users believe that performance expectancy is one of the most important antecedents of behavioral intention. In this regard, the following hypothesis will be tested in this paper:

H1: Performance expectancy has a statistically significant effect on behavioral intention to use mobile banking services.

The second construct which builds UTAUT model is effort expectancy. Venkatesh et al. (2003, p. 450) define effort expectancy as the degree of ease associated with the use of the system. The easier the mobile banking is to use, the greater the likelihood that clients will use it to conduct their banking transactions. In their research, Bankole et al. (2011), exploring the antecedents of mobile banking in Nigeria, have proven that the effort expectancy has a positive impact on the behavioral intention to use mobile banking services. Bhatiasevi (2016) came to the same conclusion in his research conducted to identify the factors leading to the adoption of mobile banking in Thailand, as did Albashrawi et al. (2017) by observing a sample of U.S. bank clients. Starting from the above, one can assume the following:

H2: Effort expectancy has a statistically significant effect on behavioral intention to use mobile banking services.

The following construct refers to social influence. Social influence refers to the degree to which an individual perceives that important others believe he or she should use the new system (Venkatesh et al., 2003, p. 451), and is particularly important in the early stages of new technology development when most users do not have experience or information about technology, and therefore rely on public opinion (Marinkovic \& Kalinic, 2017). In fact, it concerns the influence of people from the immediate surroundings of the individual (family, friends, superiors) on his or her perceptions and behavior related to a certain activity. Many studies have confirmed that social influence is directly related to the intention of an individual to use mobile banking services (Bhatiasevi, 2015; Tan \& Leby Lau, 2016). Moreover, in some research this factor has been singled out as the most significant when it comes to the intention of using mobile banking (Venkatesh \& Zhang 2010; Yu, 2012). On the basis of the above results, the hypothesis is posed:

H3: Social influence has a statistically significant effect on behavioral intention to use mobile banking services.

The last, but not the least important construct are facilitating conditions. Facilitating conditions are defined as the degree to which an individual believes that an organizational and technical infrastructure exists to support the use of the system (Venkatesh et al., 2003, p. 453). Since the use of mobile banking services requires the availability of appropriate resources, knowledge, and technology infrastructure, it is logical to assume that of these conditions a considerable extent depends the intention of an individual to use mobile banking. This assumption was empirically proven by Zhou et al. (2010), Witeepanich et al. (2013), as well as Afshan \& Sharif (2016). Consequently, the following hypothesis will be tested in the paper:

H4: Facilitating conditions have a statistically significant effect on behavioral intention to use mobile banking services. 


\section{RESEARCH METHODOLOGY}

The conducted empirical research is based on the primary data collected on the territory of Sumadija, Central Serbia, by interviewing 313 respondents with different demographic characteristics. The questionnaire technique was used to collect data, and was distributed to respondents personally and online in the period from August 17, 2018 until September 10, 2018. ${ }^{1}$ The questionnaire includes 18 statements measured on the seven-point Likert scale related to the antecedents of mobile banking according to the UTAUT model and intention to use mobile banking services, where respondents rounded out a score of 1 (I absolutely disagree) to 7 (I absolutely agree) to express their agreement with given statements. Statements are taken from relevant domestic and foreign literature, and are grouped in five variables. Along with statements, the questionnaire includes four questions related to respondent data.

The analysis of the collected primary data was performed using the statistical software SPSS v. 20, where the descriptive statistical analysis for sample structure (Table 1), reliability analysis by calculating Cronbach's alpha coefficient and correlation analysis were conducted. Starting from the work of Venkatesh et al. (2003), who used multiple regression in their research to examine the impact of constructs on behavior intentions, the same analysis was carried out in this paper, also using SPSS v. 20.

\begin{tabular}{lccc}
\hline \multirow{2}{*}{ Gender } & Femographic characteristics & Number & Percentage \\
\cline { 2 - 4 } & Male & 180 & $57.5 \%$ \\
\hline \multirow{3}{*}{ Age } & $18-24$ & 133 & $42.5 \%$ \\
\cline { 2 - 4 } & $25-44$ & 69 & $22 \%$ \\
\cline { 2 - 4 } & $45-54$ & 158 & $50.5 \%$ \\
\hline \multirow{3}{*}{ Level of education } & 55 and more & 60 & $19.2 \%$ \\
\cline { 2 - 4 } & Secondary education & 26 & $8.3 \%$ \\
\cline { 2 - 4 } & Higher education & 59 & $30.4 \%$ \\
\hline \multirow{3}{*}{ Working status } & University degree & 159 & $18.8 \%$ \\
\cline { 2 - 4 } & Employee & 153 & $50.8 \%$ \\
\cline { 2 - 4 } & Unemployee & 61 & $48.9 \%$ \\
\hline & Student & 12 & $25.9 \%$ \\
\hline
\end{tabular}

Table 1. Sample structure

Source: Authors

Based on the results obtained, it is evidenced that the majority of the sample are female respondents (57.5\%), while men represent $42.5 \%$ of the sample. Respondents are predominantly aged 25 to 44 years (50.5\% of the sample), the percentage of respondents aged 18 to $24(22 \%)$ and 45 and 54 years $(19.2 \%)$ is approximately equal, while the smallest percentage of respondents are those aged 55 and up (8.3\%). More than half of the sample includes respondents who have obtained a university degree $(50.8 \%)$, followed by those with secondary education (30.4\%) and the smallest amount being

1 Raw data used for analysis are available at the following URL address: https://data.mendeley.com/datasets/dhh4mmw3f3/1/ files/95d39de7-22ad-4b3e-945f de84a4f3329e/Antecedents\%20of\%20mobile\%20banking\%20\%20UTAUT\%20model. $\mathrm{xlsx}$ ?dl=1. 
those with higher education (formal education between secondary education and university degree) $(18.8 \%)$. When it comes to working status, as the last demographic characteristic, the sample has the highest number of employed respondents (48.9\%), followed by unemployed respondents (25.9\%), with fewer students (21.4\%), and pensioners representing the smallest group (3.8\%).

\section{RESEARCH RESULTS}

The reliability analysis was performed to test the reliability of the UTAUT variables, as well as the intention to use, i.e., the dependent variable. The results of the analysis are shown in Table 2:

\begin{tabular}{|c|c|}
\hline Variable & Cronbach's Alpha \\
\hline Performance expectancy & 0.895 \\
\hline Effort expectancy & 0.954 \\
\hline Social influence & 0.954 \\
\hline Facilitating conditions & 0.937 \\
\hline Intention to use & 0.973 \\
\hline
\end{tabular}

Table 2. Reliability analysis

Source: Authors

Table 2 gives the values of the Cronbach's Alpha reliability coefficient. Since all the values obtained are greater than 0.7 , it is concluded that all observed variables are reliable, with the highest reliability of the variable intention to use, with performance expectancy being the variable with the lowest degree of reliability.

The correlation analysis determines the degree of linear dependence between the variables of the research expressed as the value of the Pearson correlation coefficient. The values of this coefficient are shown in Table 3:

\begin{tabular}{lccccc}
\hline & $\begin{array}{c}\text { Performance } \\
\text { expectancy }\end{array}$ & $\begin{array}{c}\text { Effort } \\
\text { expectancy }\end{array}$ & $\begin{array}{c}\text { Social } \\
\text { influence }\end{array}$ & $\begin{array}{c}\text { Facilitating } \\
\text { conditions }\end{array}$ & $\begin{array}{c}\text { Intention } \\
\text { to use }\end{array}$ \\
\hline Performance expectancy & 1 & $0.815^{* *}$ & $0.527^{\star *}$ & $0.668^{\star *}$ & $0.754^{* *}$ \\
\hline Effort expectancy & $0.815^{\star *}$ & 1 & $0.555^{* *}$ & $0.755^{* *}$ & $0.749^{* *}$ \\
\hline Social influence & $0.527^{* *}$ & $0.555^{* *}$ & 1 & $0.706^{* *}$ & $0.709^{* *}$ \\
\hline Facilitating conditions & $0.668^{* *}$ & $0.755^{* *}$ & $0.706^{* *}$ & 1 & $0.764^{* *}$ \\
\hline Intention to use & $0.754^{* *}$ & $0.749^{* *}$ & $0.709^{* *}$ & $0.764^{* *}$ & 1 \\
\hline
\end{tabular}

** Correlation is significant at the 0.01 level

Table 3. Correlation analysis

Source: Authors

The results of the correlation analysis indicate that there is a statistically significant correlation, with a probability of $99 \%$, among all pairs of variables. A strong correlation exists between the majority of variables (performance expectancy and effort expectancy, performance expectancy and facilitating conditions, performance expectancy and intention to use, effort expectancy and facilitating conditions, 
effort expectancy and intention to use, social influence and facilitating conditions, social influence and intention to use, facilitating conditions and intention to use), while a moderate correlation occurs between the variables of performance expectancy and social influence, and between effort expectancy and social influence.

Regression analysis is carried out to test the set of research hypotheses that relate to the impact of independent variables (variables of the UTAUT model) on the dependent variable Intention to use. The results of this analysis are shown in Table 4:

\begin{tabular}{lccc}
\hline \multicolumn{1}{c}{ Independent variable } & $\boldsymbol{\beta}$ & Sig & VIF \\
\hline Performance expectancy & 0.328 & 0.000 & 3.060 \\
\hline Effort expectancy & 0.149 & 0.010 & 3.910 \\
\hline Social influence & 0.296 & 0.000 & 2.017 \\
\hline Facilitating conditions & 0.224 & 0.000 & 3.236 \\
\hline
\end{tabular}

Rsquare $\left(\mathrm{R}^{2}\right)=0.740 ; \mathrm{F}=218.862(\mathrm{p}<0.05)$

Table 4. Multiple regression analysis (dependent variable Intention to use)

Source: Authors

Based on the value of the VIF coefficient, it can be seen that the data are suitable for carrying out multiple regression analysis (VIF less than 5). The value of the Rsquare determination coefficient indicates that $74 \%$ of the variability of the dependent variable intention to use is explained by the given regression model. Sig value from the third column of the table shows that all independent UTAUT model variables have a statistically significant effect on the clients' intention to use mobile banking services, with the strongest impact of the variable performance expectancy $(\beta=0.328, \mathrm{p}<0.05)$, followed by the variable social influence $(\beta=0.296, \mathrm{p}<0.05)$, followed by facilitating conditions $(\beta=0.224, \mathrm{p}<0.05)$, with the weakest effect being that of effort expectancy $(\beta=0.149, p<0.05)$.

\section{CONCLUSIONS}

The aim of the conducted research is to identify the key antecedents of the intention of clients to use mobile banking services, emphasizing the components of the UTAUT model and their influence on intention to use mobile banking. Research hypotheses were tested using a multiple regression analysis, whose results indicate that all four components of the UTAUT model (performance expectancy, effort expectancy, social influence, and facilitating conditions) determine intention to use mobile banking, and it is therefore concluded that all the tested hypotheses have been proven. The performance expectancy has been highlighted as the strongest antecedent, which is consistent with the results of previous research (Baptista \& Oliveira, 2015; Basri, 2018), while the weakest antecedent is that of effort expectancy. The significance of the conducted research is based on the fact that its results enable us to gain new relevant knowledge of mobile banking antecedents, a good starting point for future research has been created and the UTAUT model has been practically tested in this segment. On the basis of the obtained results, bank managements can make optimal business decisions related to investments in the development of mobile banking. Research limitations relate to a small sample of respondents, with a sample limited to clients in Central Serbia, and neglecting the moderator's effects when it comes to the demographic characteristics of the respondents. Furthermore, the multiple regression analysis is used for testing the relationships of independent and dependent variables. It is therefore recommended to increase the sample of respondents for future papers, since results cannot be generalized, 
as the sample structure does not represent the Serbian average, from demographic and educational point of view. For future research, it might be desirable to include demographic characteristics, such as gender and age, in the research model in order to examine their moderator effect. When it comes to testing relationships between variables, the SEM (Structural Equation Modeling) approach would be more appropriate for analysis, since multiple regression analysis has limitations, such as the use of a small number of indicators, omission of measurement errors, one or more independent variables are included in the analysis but only one dependent variable etc. (Jeon, 2015). It is desirable to conduct a t-test or one-way Anova, in order to obtain more precise results when considering the demographic characteristics of the respondents. In addition, future research may rely on an extended version of the research model, by adding variables such as trust, perceived risk, dimensions of national culture, and so on. The banks are recommended to put the greatest emphasis on the performances that clients expect when it comes to mobile banking to, during the promotion of their services take into account the social influences to which their target markets are exposed, and to use those influences to make a more convincing promotional message. It is also necessary to provide good technical infrastructure and support, in order for clients to use mobile banking services without any difficulties. Finally, as effort expectancy has proven to be an important antecedent of the intention to use mobile banking, it is recommended to let clients know about the availability of the appropriate instructions or info lines for free calls to inform themselves about the correct way to access and use the mobile banking system.

\section{REFERENCES}

Afshan, S., \& Sharif, A. (2016). Acceptance of mobile banking framework in Pakistan. Telematics and Informatics, 33(2), 370-387. DOI:10.1016/j.tele.2015.09.005

Alalwan, A. A., Dwivedi, Y. K., \& Rana, N. P. (2017). Factors influencing adoption of mobile banking by Jordanian bank customers: Extending UTAUT2 with trust. International Journal of Information Management, 37(3), 99-110. DOI:10.1016/j.ijinfomgt.2017.01.002

Albashrawi, M., Kartal, H., Oztekin, A., \& Motiwalla, L. (2017). The Impact of Subjective and Objective Experience on Mobile Banking Usage: An Analytical Approach. In Proceedings of the 50th Hawaii International Conference on System Sciences. HICSS Conference Office. 4-7 January 2017 (pp.1161-1170). DOI:10.24251/ hicss.2017.137

Alkhunaizan, A., \& Love, S. (2012). What drives mobile commerce?, An empirical evaluation of the revised UTAUT model. International Journal of Management and Marketing Academy, 2(1), 82-99.

Bankole, F. O., Bankole, O. O., \& Brown, I. (2011). Mobile Banking Adoption in Nigeria. The Electronic Journal of Information Systems in Developing Countries, 47(1), 1-23. DOI:10.1002/j.1681-4835.2011.tb00330.x

Baptista, G., \& Oliveira, T. (2015). Understanding mobile banking: The unified theory of acceptance and use of technology combined with cultural moderators. Computers in Human Behavior, 50, 418-430. DOI:10.1016/j. chb.2015.04.024

Basri, S. (2018). Determinants of adoption of mobile banking: evidence from rural Karnataka in India. International Journal of Trade and Global Markets, 11(1/2), 77-86. DOI:10.1504/ijtgm.2018.092490

Bhatiasevi, V. (2016). An extended UTAUT model to explain the adoption of mobile banking. Information Development, 32(4), 799-814. DOI:10.1177/0266666915570764

Bhatt, A., \& Bhatt, S. (2016). Factors Affecting Customer's Adoption of Mobile Banking Services. Journal of Internet Banking and Commerce, 21(1), 1-22.

Jeon, J. (2015). The strengths and limitations of the statistical modeling of complex social phenomenon: Focusing on SEM, path analysis, or multiple regression models. International Journal of Social, Behavioral, Educational, Economic, Business and Industrial Engineering, 9(5), 1559-1567. DOI:10.5281/zenodo.1105869 
Marinkovic, V., \& Kalinic, Z. (2017). Antecedents of customer satisfaction in mobile commerce: exploring the moderating effect of customization. Online Information Review, 41(2), 138-154. DOI:10.1108/oir-112015-0364

Min, Q., Ji, S., \& Qu, G. (2008). Mobile commerce user acceptance study in China: A revised UTAUT model. Tsinghua Science and Technology, 13(3), 257-264. DOI:10.1016/s1007-0214(08)70042-7

Oliveira, T., Faria, M., Thomas, M.A., \& Popovič, A. (2014). Extending the understanding of mobile banking adoption: When UTAUT meets TTF and ITM. International Journal of Information Management, 34(5), 689-703. DOI:10.1016/j.ijinfomgt.2014.06.004

Samudra, M.S., \& Phadtare, M. (2012). Factors Influencing the Adoption of Mobile Banking with Special Reference to Pune City. ASCI Journal of Management, 42(1), 51-65. DOI:10.12691/jbms-6-1-2

Sanader, D. (2014). Mobile banking: New trend in thecontemporary banking sector. Bankarstvo, 43(5), 86-109. DOI:10.5937/bankarstvo1405086s

Sarfaraz, J. (2017). Unified Theory of Acceptance and Use of Technology (UTAUT) Model-Mobile Banking. Journal of Internet Banking and Commerce, 22(3), 1-20.

Tarhini, A., El-Masri, M., Ali, M., \& Serrano, A. (2016). Extending the UTAUT model to understand the customers' acceptance and use of internet banking in Lebanon. Information Technology and People, 29(4), 830-849. DOI:10.1108/itp-02-2014-0034

Tan, E., \& Leby, L. J. (2016). Behavioural intention to adopt mobile banking among the millennial generation. Young Consumers, 17(1), 18-31. DOI:10.1108/yc-07-2015-00537

Venkatesh, V., Morris, G.M., Davis, B.G., \& Davis, D.F. (2003). User Acceptance of Information Technology: Toward a Unified View. MIS Quarterly, 27(3), 425-478. DOI:10.2307/30036540

Venkatesh, V., \& Zhang, X. (2010). Unified Theory of Acceptance and Use of Technology: U.S. Vs. China. Journal of Global Information Technology Management, 13(1), 5-27. DOI:10.1080/1097198x.2010.10856507

Venkatesh, V., Thong, J.Y.L., Chan, F. K. Y., Hu, P. J. H., \& Brown, S. A. (2011). Extending the two-stage information systems continuance model: incorporating UTAUT predictors and the role of context. Information Systems Journal, 21(6), 527-555. DOI:10.1111/j.1365-2575.2011.00373.x

Venkatesh, V., Thong, J. Y. L., \& Xu, X. (2012). Consumer Acceptance and Use of Information Technology: Extending the Unified Theory of Acceptance and Use of Technology. MIS Quarterly, 36(1), 157-178. DOI:10.2307/41410412

Witeepanich, C., Emklang, N., Matsmak, J., Kanokviriyasanti, P., \& Chanvarasuth, P. (2013). Understanding the Adoption of Mobile Banking Services: an Empirical Study. In Proceedings of the 4th International Conference on Engineering, Project, and Production Management. Bangkok, Thailand: The Sukosol. 2013 (pp. 282-291). October; 23-25.

Yao, H., \& Zhong, C. (2011). The Analysis of Influencing Factors and Promotion Strategy for the Use of Mobile Banking. Canadian Social Science, 7(2), 60-63. DOI:10.3968/j.css.1923669720110702.008

Yu, C. (2012). Factors affecting individuals to adopt mobile banking: Empirical evidence from the UTAUT model. Journal of Electronic Commerce Research, 13(2), 104-121.

Zhou, T., Lu, Y., \& Wang, B. (2010). Integrating TTF and UTAUT to explain mobile banking user adoption. Computers in Human Behavior, 26(4), 760-767. DOI:10.1016/j.chb.2010.01.013 


\section{APPENDIX}

\begin{tabular}{|c|c|c|}
\hline Variable & Statements & Source \\
\hline $\begin{array}{l}\text { Performance } \\
\text { Expectance }\end{array}$ & $\begin{array}{l}\text { 1. Using mobile banking services helps me accomplish things more } \\
\text { quickly. } \\
\text { 2. Using mobile banking would make it easier for me to carry out my } \\
\text { tasks. } \\
\text { 3. I find mobile banking services useful in my daily life. }\end{array}$ & $\begin{array}{l}\text { Addapted from: } \\
\text { Al-Jabri (2015); } \\
\text { Venkatesh et al., } \\
\quad(2012)\end{array}$ \\
\hline $\begin{array}{c}\text { Effort } \\
\text { Expectance }\end{array}$ & $\begin{array}{l}\text { 4. I find mobile banking services easy to use. } \\
\text { 5. Learning how to use mobile banking services is easy for me. } \\
\text { 6. I think the interaction with mobile banking does not require a lot } \\
\text { of mental effort. } \\
\text { 7. Mobile banking services are easily accessible. }\end{array}$ & $\begin{array}{c}\text { Addapted from: } \\
\text { Samudra, Phad- } \\
\text { tare, } 2012 \\
\text { Venkatesh et al., } \\
\text { (2012); } \\
\text { Al-Jabri (2015); } \\
\text { Gašević et al., } \\
\text { (2016) }\end{array}$ \\
\hline $\begin{array}{c}\text { Social } \\
\text { Influence }\end{array}$ & $\begin{array}{l}\text { 8. People who are important to me think that I should use mobile } \\
\text { banking services. } \\
\text { 9. People who are familiar with me think that I should use mobile } \\
\text { banking. } \\
\text { 10. People who influence my behaviour think that I should use mobile } \\
\text { banking services. } \\
\text { 11. Most people surrounding with me use mobile banking. }\end{array}$ & $\begin{array}{l}\text { Addapted from: } \\
\text { Venkatesh et al., } \\
\quad(2012) ; \\
\quad \text { Yu (2012) }\end{array}$ \\
\hline $\begin{array}{l}\text { Facilitating } \\
\text { Conditions }\end{array}$ & $\begin{array}{l}\text { 12. My living environment supports me to use mobile banking. } \\
\text { 13. My working environment supports me to use mobile banking. } \\
\text { 14. I can get help from others when I have difficulties using mobile } \\
\text { banking services. }\end{array}$ & $\begin{array}{l}\text { Addapted from: } \\
\text { Venkatesh et al., } \\
\quad(2012) ; \\
\text { Yu (2012) }\end{array}$ \\
\hline $\begin{array}{l}\text { Behavioral } \\
\text { Intention }\end{array}$ & $\begin{array}{l}\text { 15. I intend to use mobile banking. } \\
\text { 16. I would use mobile banking. } \\
\text { 17. I would see myself using mobile banking for handling my banking } \\
\text { transactions. } \\
\text { 18. I think it is a wise idea to use mobile banking services. }\end{array}$ & $\begin{array}{l}\text { Yu (2012); } \\
\text { Al-Jabri (2015); } \\
\text { Dasgupta et al., } \\
\quad(2011)\end{array}$ \\
\hline
\end{tabular}

Table 5. Variables and corresponding statements

Source: Authors 


\section{ANTECEDENTE MOBILNOG BANKARSTVA: UTAUT MODEL}

\section{Rezime:}

Razvoj savremenih informaciono-komunikacionih tehnologija omogućio je bankama da se u svom poslovanju oslone na mobilno bankarstvo kao važan distributivni kanal. S obzirom na to da su ulaganja u razvoj mobilnih bankarskih sistema izuzetno velika, saznanja o tome koji faktori utiču na namere pojedinaca da koriste usluge mobilnog bankarstva mogu biti od velikog značaja. $U$ te svrhe, sprovedeno je empirijsko istraživanje i anketirano je 313 ispitanika na teritoriji Šumadije, centralna Srbija. Prikupljeni primarni podaci analizirani su u statističkom softveru SPSS v. 20. Za ispitivanje faktora u radu se koristi UTAUT model (eng. The unified theory of acceptance and use of technology). Rezultati empirijskog istraživanja ukazuju na to da sve komponente UTAUT modela imaju statistički značajan uticaj na nameru korišćenja mobilnog bankarstva, pri čemu su se kao najvažnije antecedente izdvojile očekivane performanse, dok najslabiji uticaj ima očekivani napor. U radu se potvrđuje uspešnost primene UTAUT modela za ispitivanje antecedenti mobilnog bankarstva i stečena su nova saznanja u vezi sa namerom korišćenja mobilnog bankarstva u Srbiji koja mogu poslužiti u menadžerske svrhe.
Ključne reči:

savremene tehnologije, mobilno bankarstvo, namera korišćenja mobilnog bankarstva, UTAUT model. 